\title{
TRANSACTIONS
}

OF THE

\section{ROYAL HISTORICAL SOCIETY}

\author{
EDITED BY THE \\ REV. CHARLES ROGERS, LL.D., \\ HISTORIOGRAPHER TO THE ROYAL HISTORICAL SOCIETY; FELLOW OF THE \\ SOCIETY OF ANTIQUARIES OF SCOTLAND ; AND CORRESPONDING \\ MEMBER OF THE HISTORICAL AND GENEALOGICAL \\ SOCIETY OF NEW ENGLAND.
}

VOL. III.

N E W SER I ES.

\begin{abstract}
L O N D O N :
PRINTED FOR THE SOCIETY, I 874 .
\end{abstract}


LONDON :

J. AND W. RIDER, PRINTERS,

BARTHOLOMEW CLOSE. 


\section{CONTENTS.}

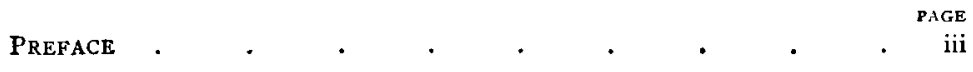

List of Fellows of THE Society $\quad$ - $\quad$ - $\quad$ - $\quad$ - $\quad$ - iv

Domestic Every-day Life, Manners and Customs, in the Ancient

World. By George Harris, Esq., F.S.A., F.R.H.S. . . . I

Oi.d-found Lands in North America. By Thomas Morgan, Esq., F.R.H.S.

The Rise of the English Legal Profession. By J. W. Hill, Esq., of Trinity Coliege, Cambridge, and of the Middle TEMPle, BarRISTER-AT-LAW, F.R.H.S. $\quad$ • $\quad$ • $\quad$ - 98

Three Poets of the Scottish Reformation: Alexander Cunningham, Fifth Earl of Glencairn; Henry Balnaves of Halhill; and John Davidson, Minister at Prestonpans. By the Rev. Charles Rogers, LL.D., F.R.H.S., F.S.A. Scot., and Cor. Mem. of the Hist. Soc. of New England . • I63

The Great Mace and other Corporation Insignia of the Borough of Leicester: With an APPENDix on Corporate Emblems and Insignia in England and Wales. By William KELLY, Esq., F.R.H.S.

Adventures of a Bohemian Norleman in Palestine and Egypt in the Days of Queen Elizabeth. By the Rev. A. H. WRATISLAW, F.R.H.S. . . . . . . 346

Notes in the History of British Life Assurance. By George Tomkins, Esq., F.K.H.S. • . • . • • . 376 
On the Possibility of a Strictly Scientific Treatment of PAGE Universal History. By Gustavus George Zerffi, Esq., Ph.D., F.R.H.S.

Malta and its Knights. By the Rev. Samurl Cowdy, Ll.D., F.R.H.S.

The Art. Revival in Italy. By George Browning, Esq., F.R.H.S., Hon. Sec. for the Encouragement of the Fine Arts ${ }_{i} \quad . \quad 408$

Some Account of Sir Audley Mervyn, His Majesty's Prime Sergeant and Speaker in the House of Commons in Ireland, From 166i till 1666. By John P. Prendergast, Esq., BarristerAT-LAW, AND HoN. F.R.H.S. . 